\title{
THE USE OF FOLKTALES IN TEACHING LISTENING COMPREHENSION
}

\author{
Muhammad Asrul Sultan \\ UPP PGSD Parepare Fakultas Ilmu Pendidikan UNM \\ lulling01@gmail.com
}

\begin{abstract}
The objectives of this research are: (1) To find out whether or not the use of folktales in teaching listening comprehension is effective to improve the students' listening comprehension ability and (2) To elaborate the students motivation toward the use of folktales in teaching listening comprehension is effective to improve the students' listening comprehension ability. This research is a quasi experimental research and it employed a cluster random sampling technique. The researcher randomly select two class from six class of the tenth years students. Group A was as experimental group and group B became control group. The data were collected by using test and questionnaire. The data of the students' learning outcomes on listening were collected by using listening test while the data on the students' motivation were collected by using questionnaire. Those data were then analyzed descriptively and inferentially using SPSS 16.0 and Likert Scale.The result of data analysis indicated that: (1) the learning outcomes on listening of the tenth years students of SMA Negeri 1 Parepare taught by using folktales in teaching listening significantly increased after the treatment. "The use of folktales in teaching listening comprehension" effective in improving listening comprehension achievement of the students better than conventional activity as indicated by the t-test value 7.571 and the p-value (2-tailed) .000 which was not greater than 05 level of significance; (2) the students were motivated in learning listening by using folktales, as indicated by the mean score 83.83 from the questionnaire. It means that the students were classified strongly motivated students.
\end{abstract}

Key words: folktales and listening comprehension

\section{INTRODUCTION}

Listening as one of the four language skills is aural and receptive skill. This is a very essential in communication because we cannot catch someone's idea that is transmitted to us if we do not have a good listening ability. White (1998) found that people listen $45 \%$ of the time they spent communicating. He also found that $30 \%$ of communicating time was spent speaking, $16 \%$ reading, and 9\% writing. Clearly, much of the educational process is based on listening skill. Students have to spend most of the time listening to what the teacher says, for instance, giving lectures, asking questions, or telling directions.

Based on the information from an English teacher of SMA NEGERI 1 Parepare through observation to the teaching learning process in the classroom, especially at the eleventh grade, the students' achievement in Listening comprehension is low. As a value observation in the classroom the students' score is about 5 , in the last semester the students score between 20 - 40 while the $\mathrm{KKM}$ is 70 . This score is as a category poor. It is because the students seldom practice listening in teaching-learning process. They tend to focus on writing and grammar. Therefore, the researcher wants to overcome this problem until the students get a good achievement by using an approach that related to the student's problem has been talked.

As long some approaches had been applied to improve the students' listening comprehension at the school, but those approaches still weak, in the other words those approaches are not significant to improve the students' achievement in listening comprehension. In this case the writer would like to introduce that is assumed to be success to improve the students' listening comprehension. It is called Aural-Oral Language Approach. Hasan (2000) pointed out, "listening 
comprehension provides the right conditions for language acquisition and development of other language skills" (p.138).

Most teachers agree that listening comprehension is one of the most important skills and one of the most difficult language skills to teach to the students of English in a country where English is a foreign language (EFL) or for the second language (SLA). One of the reasons for this is that is required more than just an ability to listen. Harmer (1991) points out that as person is listening, he is actually employing a number of special skills which will determine his success at understanding the context that he hears, they are predictive skills, extracting specific information, getting the general picture, and inferring opinion and attitude.

Gebhard (2000: 144) argues that in comprehending spoken English (listening), there are two distinct processes, namely; bottom-up processing and top-down processing. The first process (bottom-up) refers to a process of decoding a message that the listener hears through the analysis of sounds, words, and grammar, while the second (top-down) refers to using background knowledge to comprehend the message. He therefore argues that while successful bottom-up processing relies on recognition of sound, words, and grammar, successful top-down processing hinges on having the kind of background knowledge needed to comprehend the meaning the message where this can be in the form of previous knowledge about the topic.

The statements above guide us to interpret, to construct and to evaluate to teaching or learning English especially listening subject. As receptive skill, listening at least requires basic skill or there must be sufficient basic in listening skill. Vocabulary mastery for instance where it is also stated in bottom up processing. The students who master the vocabulary can identify or decode the sound or the word that they listen and it will support to comprehend the meaning of such message. Comprehending the meaning of message is not only based on the vocabulary (even though this basic skill is required absolutely), but also the student's basic knowledge. This basic knowledge gained by learning formally (education, religion and so on) and informally (social or cultural interaction). In other word, the students who get unfamiliar text (material) in their class will face difficult in interpreting or perceiving the message of such text even though they have enough or sufficient vocabulary.

In order to help the students to acquire listening skill, teachers in teaching listening should provide selective material and variety techniques or approaches. One way to make our national education more competitive is use more application of instructional and material in teaching process. The fact some English teachers still use conventional method in teaching listening in the class room, that's make the students fell bored and think that listening is difficult subject, and the situation this was happen in SMA Negeri I Parepare.

Media is one of tools which can use the teachers to transmit idea to the students and motivation the students. Using folktales as media in teaching English helps sensitivity to students' sense of hearing. Many students like literary work so much and it could make the students learning process easier. They will be motivated and happy to learn English and using folktales can improve their listening comprehension.

Irmawati (2008) in her thesis "Improving students' listening comprehension through kangaroo radio English in the classroom" found out that the students' listening comprehension achievement was improved by the use of KGRE in the classroom as a program which provides authentic material and teaching strategies and the students were motivated in learning listening comprehension using KGRE in the classroom. He added that KGRE in the classroom-where it prepare authentic material and teaching strategies -is where to boost the students' listening performance and were importantly to guide teachers about some effective ways of 
devising teaching strategies in the classroom and giving tips and ideas about how to create activities.

According to Ellies (1994), examining that the art in listening research, notes the lack of agreement upon definition of listening. Listening is the basis for the development of all other skills and the main channel through which the student makes initial contact with the target language and its culture. Through active listening, students acquire vocabulary and syntax, as well as better pronunciation, accent and intonation. Though listening skill is very important, for some language learners it is considered to be the most difficult language skill (Etman, 2009). Brown (2001:247) stated that the importance of listening in language learning can hardly be overestimated. Through reception, we internalize linguistic information without which we could not produce language.

Folktales are a literary work with not only deal with literature, but also with sociology, history and anthropology. Teaching using folktales is very suitable to be applied to the students of senior high school as a media in teaching listening because folktales not only used in educational materials for students but also can motivating and encourage students' interest in learning English. Muhtar (2010) in her research "using folktales in teaching reading to the second years students of SMP Negeri 6 Makassar" found out that there was improvement on the students' reading comprehension in experiment group after treatment using Folktales. She assumed that using folktales does not only improve the students' reading comprehension and motivation, but also entertain the students. Folktales broaden the students' mind, and it is according to the students' mood, preferences, taste, intellectual demand and cultural development.

Actually folktales also fit in not only with the literature but also with sociology, history, and anthropology. Folktales are very popular for all people because everyone has story to tell. Eric
Taylor (2002) state that a term of folktales is used of several related kind of stories. Most narrowly folktale is a traditional story that has been passed on by word of mouth-told from parent to child over many generations or passed on by countless storytellers sitting around countless evening fires. No one knows who is the original author was, and there are usually different versions of the same story.According to Harmer (1992: 157) motivation is some kind of internal dive that encourages somebody to pursue a course of action. If we perceive a goal and if that goals are sufficiently attractive, we will be strongly motivated to do whatever is necessary to reach that goal.

Based on statement above, the researcher then decided to apply using folktales in teaching listening comprehension. It was held at the tenth year of SMA Negeri 1 Parepare. In that school, the researcher has found some problems related to listening comprehension faced by the students. The students were still lack of interest in learning listening comprehension. The researcher formulated the objectives of this research were: 1 . Is the use of folktales in teaching listening comprehension effective to improve the students' listening comprehension ability?, 2. Are the students motivated to use of folktales in teaching listening comprehension?

\section{METHOD}

Design and Samples

This study was a quantitative study using quasi experimental research. The researcher divided the research object into two groups, experimental group who was given treatment, and the control group without treatment. This division was intended to test the hypothesis to know the condition after treatment. A pre-test was administered prior to the treatment to assess their current competence of language skills and a post-test was administered later to measure the effect of the treatment. The research was designed by giving the pre-test and post-test to both groups, the experimental and control 
groups. The pre-test would be administered in order to know the students prior knowledge while the post-test was given to find out the effectiveness of the use of folktales in teaching listening comprehension to improve the students' listening comprehension ability. The population of this research was the tenth year students of SMA Negeri I Parepare 2013/2014 academic year. It consisted of six classes and 35 students each class. So the total number of population was 210 students. The sample of this research had been selected through cluster random sampling, in which intact groups, not individuals, were randomly selected (Gay, 2006: 106). It meant that from six classes of population, the researcher chose two classes randomly to represents the experimental and control group. Cluster random sampling was more convenient when the population was quite large and it would have a much better chance of securing permission to work with all students in several classrooms than to work with a few students in many classrooms. Class A would be taken as experimental group and class B would be taken as control group. As a consideration, the students of both classes had the same ability. Besides the students also had the same background knowledge in learning English

\section{Instruments and Procedure}

The instruments used to collect the data consisted of two kinds of instrument, namely; listening comprehension test and questionnaire. In the procedure of collecting data, the researcher collected the data by administering of pretest, posttest, and questionnaire. The researcher gave the treatment to the students of experimental group and control group. The data were collected from the test of listening comprehension test that was analyzed by using the following procedures:

a. Scoring the students' answer of pretest and posttest. b. Tabulating the score of the students test both experimental group and control group.

c. Converting and classifying the scores of the students into five levels as follows:

Table 3.1. Scoring Classification of the Students' Learning Outcomes on Listening Test.

\begin{tabular}{|l|l|}
\hline Score & Classification \\
\hline $91-100$ & Very good \\
\hline $76-90$ & Good \\
\hline $61-75$ & Fair \\
\hline $51-60$ & Poor \\
\hline Less than 50 & Very poor \\
\hline
\end{tabular}

(Depdiknas, 2008)

d. Calculating the means score, standard deviation and t-test using SPSS 16.0 program for Windows to gain accurate quantification.

e. The data of the students' motivation from the questionnaire would be classified by using following procedure.

1. Scoring the student's motivation toward the use of folktale in teaching listening used the following, scale : likert scale

Table Likert scale

\begin{tabular}{|l|l|l|l|}
\hline \multicolumn{2}{|l|}{ Positive Statement } & \multicolumn{2}{|l|}{ Negative Statement } \\
\hline Category & Score & Category & Score \\
\hline $\begin{array}{l}\text { Strongly } \\
\text { agree }\end{array}$ & 5 & $\begin{array}{l}\text { Strongly } \\
\text { agree }\end{array}$ & 1 \\
\hline Agree & 4 & Agree & 2 \\
\hline Neutral & 3 & Neutral & 3 \\
\hline Disagree & 2 & Disagree & 4 \\
\hline $\begin{array}{l}\text { Strongly } \\
\text { disagree }\end{array}$ & 1 & $\begin{array}{l}\text { Strongly } \\
\text { disagree }\end{array}$ & 5 \\
\hline
\end{tabular}

(Syaodih, 2008)

Formula of mean score:

$X=\frac{\sum X}{N}$

Where:

$\mathrm{X} \quad=$ The mean score

$\Sigma \mathrm{X}=$ Total mean score

$\mathrm{N} \quad=$ Total respondent

(Gay, 2006)

2. Categorizing the student's motivation toward The use of folktales in teaching listening comprehension 
Table The interval score on the questionnaire

\begin{tabular}{|c|l|}
\hline Interval score & Category Motivation \\
\hline $88-100$ & Very high motivated \\
$71-87$ & Strong motivated \\
$54-70$ & Moderate \\
$37-53$ & Weak motivated \\
$20-36$ & Very weak motivated \\
\hline
\end{tabular}

\section{RESULT AND DISCUSSIONS}

1. The Improvement of the Tenth Year Students of SMA NEGERI I Parepare in Listening Comprehension Before and After Treatment.

a. The Results of listening test in Experimental Class

The Rate Percentage of the Students' Listening Tests in Experimental Group

\begin{tabular}{|l|l|l|l|l|l|l|}
\hline No & Classifi & \multirow{2}{*}{$\begin{array}{l}\text { Score } \\
\text { Rang } \\
\text { cation }\end{array}$} & \begin{tabular}{l} 
e \\
\cline { 3 - 7 }
\end{tabular} & Pretest & $(\%)$ & \multicolumn{2}{l|}{ Posttest } & $(\%)$ \\
\hline 1. & $\begin{array}{l}\text { Very } \\
\text { Good }\end{array}$ & $\begin{array}{l}91- \\
100\end{array}$ & 0 & 0 & 0 & 0 \\
\hline 2. & Good & $76-90$ & 0 & 0 & 11 & 36,66 \\
\hline 3. & Fair & $61-75$ & 13 & 43,33 & 19 & 63,33 \\
\hline 4. & Poor & $51-60$ & 10 & 33,33 & 0 & 0 \\
\hline 5. & $\begin{array}{l}\text { Very } \\
\text { Poor }\end{array}$ & $<50$ & 7 & 23,33 & 0 & 0 \\
\hline \multicolumn{7}{|l|}{ Total } \\
\hline
\end{tabular}

The statistical summary depicted in Table show, pictures out the frequency and rate percentage of the students' scores of listening comprehension of both pretest and posttest. The rest of the scores remained at every level of classification, namely: in pretest, there was $7(23.33 \%)$ out of them scored into very poor classification,10 (33.33\%) out of them scored into poor classification, most of students $13(43.33 \%)$ and none of them got into good and very good classification. On the other hand, in the posttest, there were $11(36.66 \%)$ scored good classification and $19(63.33 \%)$ out of them scored into fair classification and nobody got scored into very good, poor and very poor classification.

The Findings of the Students' Pretest and Posttest on Listening
Comprehension Tests in Experimental Group

\begin{tabular}{|l|l|l|l|l|l|l|l|}
\hline $\begin{array}{l}\text { Variable } \\
\mathrm{s}\end{array}$ & $\begin{array}{l}\text { Mea } \\
\mathrm{n}\end{array}$ & $\begin{array}{l}\text { Standard } \\
\text { deviatio } \\
\mathrm{n}\end{array}$ & $\begin{array}{l}\text { Mod } \\
\mathrm{e}\end{array}$ & $\begin{array}{l}\text { Media } \\
\mathrm{n}\end{array}$ & $\begin{array}{l}\text { Min. } \\
\text { Scor } \\
\mathrm{e}\end{array}$ & $\begin{array}{l}\text { Max. } \\
\text { Scor } \\
\mathrm{e}\end{array}$ & $\mathrm{N}$ \\
\hline $\begin{array}{l}\text { Pretest } \\
\left(\mathrm{X}_{1}\right)\end{array}$ & 59.67 & 8.899 & 65 & 60 & 40 & 75 & 3 \\
\hline $\begin{array}{l}\text { Posttest } \\
\left(\mathrm{X}_{2}\right)\end{array}$ & 76.505 .894 & 75 & 75 & 70 & 90 & 3 \\
\hline
\end{tabular}

The statistical summary depicted in Table shows that the total number of subjects is 30 (thirty) students. The scores achieved by the students tend to get increased from pretest to posttest. As the result, the mean scores are classified around Good score.

Thus, the mean score in pretest was 59.67 was categorized as Fair Classification and in posttest was 76.50 was categorized as Good classification which indicated that the mean scores of students' listening comprehension in posttest was higher that the pretest. It increased 16.83 points.

b. The Results of Listening Test in control Class

The Rate Percentage of the Students' listening comprehension Tests in Control Group

\begin{tabular}{|c|c|c|c|c|c|c|}
\hline \multirow[b]{2}{*}{$\begin{array}{l}\mathrm{N} \\
\mathrm{o} .\end{array}$} & \multirow[b]{2}{*}{$\begin{array}{l}\text { Classifi } \\
\text { cation }\end{array}$} & \multirow{2}{*}{$\begin{array}{l}\text { Score } \\
\text { Rang } \\
\text { e }\end{array}$} & \multicolumn{2}{|c|}{ Pretest } & \multicolumn{2}{|c|}{ Posttest } \\
\hline & & & (f) & $\begin{array}{l}(\% \\
)\end{array}$ & (f) & $(\%)$ \\
\hline 1. & $\begin{array}{l}\text { Very } \\
\text { Good }\end{array}$ & $\begin{array}{l}91- \\
100\end{array}$ & 0 & 0 & 0 & 0 \\
\hline 2. & Good & $76-90$ & 0 & 0 & 0 & 0 \\
\hline 3. & Fair & $61-75$ & 12 & 40 & 20 & 66.66 \\
\hline 4. & Poor & $51-60$ & 9 & 30 & 6 & 20 \\
\hline 5. & $\begin{array}{l}\text { Very } \\
\text { Poor }\end{array}$ & $<50$ & 9 & 30 & 4 & 13.33 \\
\hline \multicolumn{3}{|c|}{ Total } & 30 & 100 & 30 & 100 \\
\hline
\end{tabular}

The statistical summary depicted in

Table 4.3 shows, pictures out the frequency and rate percentage of the students' scores of listening comprehension of both pretest and posttest. The rest of the scores remained at every level of classification, namely: in pretest, there was $9(30 \%)$ out of them scored into very poor classification, $9(30 \%)$ out of them scored into poor classification, and $12(40 \%)$ scored into fair classification, 
and none of them got into very good and good classification. On the other hand, in the posttest, there were $4(13.33 \%)$ out of them scored into very poor classification and $6(20 \%)$ scored into poor classification and $20(66.66 \%)$ score into fair classification. Thus, nobody students got scored into very good and good classification.

The Findings of the Students' Pretest and Posttest on Listening Comprehension Tests in Control Group

\begin{tabular}{|l|l|l|l|l|l|l|l|}
\hline Variables & Mean & $\begin{array}{l}\text { Standard } \\
\text { deviation }\end{array}$ & Mode & Median & $\begin{array}{l}\text { Min. } \\
\text { Score }\end{array}$ & $\begin{array}{l}\text { Max. } \\
\text { Score }\end{array}$ & $\mathrm{N}$ \\
\hline $\begin{array}{l}\text { Pretest } \\
\left(\mathrm{X}_{1}\right)\end{array}$ & 58.179 .603 & 65 & 60 & 35 & 75 & 30 \\
\hline $\begin{array}{l}\text { Posttest } \\
\left(\mathrm{X}_{2}\right)\end{array}$ & 63.507 .328 & 65 & 65 & 45 & 75 & 30 \\
\hline
\end{tabular}

The statistical summary depicted in Table 4.4 , shows that the total number of subjects is 30 (thirty) students. The scores achieved by the students tend to get increased from pretest to posttest. As the result, the mean scores are classified around Good score.

Thus, the mean score in pretest was 58.17 and in posttest was 63.50 which indicated that the mean scores of students' listening comprehension in posttest was higher that the pretest. It increased 5.33 points.

2. Scoring Classification of the Students' Pretest of Experimental/Control Group and Posttest of Experimental/Control Group of the Total Score of Listening Comprehension Tests.

a. The Students' Pretest of Control/Experimental Group of the Total Scores of Listening Tests.

The Rate Frequency and Percentage of the Students' Pretest of Experimental/ Control Group of the Total Score of Listening Tests.

\begin{tabular}{|c|c|c|c|c|c|c|}
\hline \multirow{2}{*}{$\begin{array}{l}\text { No } \\
\text {. }\end{array}$} & \multirow{2}{*}{$\begin{array}{l}\text { Classi } \\
\text { ficatio } \\
n\end{array}$} & \multirow{2}{*}{$\begin{array}{l}\text { Scor } \\
\mathrm{e} \\
\text { Rang } \\
\mathrm{e}\end{array}$} & \multicolumn{2}{|c|}{$\begin{array}{l}\text { Experimenta } \\
1 \text { Group }\end{array}$} & \multicolumn{2}{|c|}{$\begin{array}{l}\text { Control } \\
\text { Sroup }\end{array}$} \\
\hline & & & (f) & $(\%)$ & (f) & $(\%)$ \\
\hline 1. & $\begin{array}{l}\text { Very } \\
\text { Good }\end{array}$ & $\begin{array}{l}91- \\
100\end{array}$ & 0 & 0 & 0 & 0 \\
\hline 2. & Good & $\begin{array}{l}76- \\
90\end{array}$ & 0 & 0 & 0 & 0 \\
\hline 3. & Fair & $\begin{array}{l}61- \\
75\end{array}$ & 13 & $\begin{array}{l}43,3 \\
3\end{array}$ & 12 & 40 \\
\hline 4. & Poor & $\begin{array}{l}51- \\
60\end{array}$ & 10 & $\begin{array}{l}33,3 \\
3\end{array}$ & 9 & 30 \\
\hline 5. & $\begin{array}{l}\text { Very } \\
\text { Poor }\end{array}$ & $<50$ & 7 & $\begin{array}{l}23,3 \\
3 \\
\end{array}$ & 9 & 30 \\
\hline \multicolumn{3}{|c|}{ Total } & 30 & 100 & 30 & 100 \\
\hline
\end{tabular}

Table shows, pictures out the frequency and rate percentage of the students' scores of both pretest of control and experimental group on listening comprehension test. From this table, it can be seen that most of the students in pretest of control group, $12(40 \%)$ out of 30 students were categorized as fair classification, $9(30 \%)$ out of 30 students were categorized as poor classification, and $9(30 \%)$ students was categorized as very poor classification, and none of them were categorized as very good nor good classifications. Furthermore, in pretest of experimental group, most of the students, $13(43.33 \%)$ out of them were categorized as fair classification. The rest of the scores, $10(33.33 \%)$ out of them were classified as very poor, and $7(23.3 \%)$ out of 40 students were categorized as poor classification, and none of them were categorized as very good and good.
b. The Students' Posttest of Experimental/Control Group of the Total Scores of Listening Comprehension tests

The Rate frequency and Percentage of the Students' Posttest of Experimental / Control Group of the Total Score of Listening Comprehension Tests. 


\begin{tabular}{|c|c|c|c|c|c|c|}
\hline \multirow{2}{*}{$\begin{array}{l}\text { No } \\
\text {. }\end{array}$} & \multirow{2}{*}{$\begin{array}{l}\text { Classif } \\
\text { ication }\end{array}$} & \multirow{2}{*}{$\begin{array}{l}\text { Scor } \\
\mathrm{e} \\
\text { Rang } \\
\mathrm{e}\end{array}$} & \multicolumn{2}{|c|}{$\begin{array}{l}\text { Experiment } \\
\text { al Group }\end{array}$} & \multicolumn{2}{|c|}{$\begin{array}{l}\text { Gontrol } \\
\text { Group }\end{array}$} \\
\hline & & & (f) & $(\%)$ & (f & $(\%)$ \\
\hline 1. & $\begin{array}{l}\text { Very } \\
\text { Good }\end{array}$ & $\begin{array}{l}91- \\
100\end{array}$ & 0 & 0 & 0 & 0 \\
\hline 2. & Good & $\begin{array}{l}76- \\
90\end{array}$ & 11 & 36,66 & 0 & 0 \\
\hline 3. & Fair & $\begin{array}{l}61- \\
75\end{array}$ & 19 & 63,33 & 20 & 66.66 \\
\hline 4. & Poor & $\begin{array}{l}51- \\
60\end{array}$ & 0 & 0 & 6 & 20 \\
\hline 5. & $\begin{array}{l}\text { Very } \\
\text { Poor }\end{array}$ & $<50$ & 0 & 0 & 4 & 13.33 \\
\hline \multicolumn{3}{|c|}{ Total } & 30 & 100 & 30 & 100 \\
\hline
\end{tabular}

Table shows pictures out the frequency and rate percentage of the students' scores of both posttest control and experimental group on listening comprehension test. From this table, it can be seen that most of the students in posttest of control group $20(66.66 \%)$ out of 30 students were categorized as fair classification, $6(20 \%)$ out of 30 students were categorized as poor classification and also $4(13 \%)$ students were classified into very poor classification. On the other hand, in posttest of experimental group, most of the students, 30 out of them or equivalent to $11(36.66) \%$ percent were categorized as good classification, and the rest or 19 $(63.33 \%)$ out of 30 students were categorized as fair classification and none of them were categorized as poor or very poor classifications.

3. The comparison between the students' score of pretest and posttest in control and experimental class

The Mean Score and Standard Deviation of Students' Pretest

\begin{tabular}{|l|l|l|}
\hline Group & Mean Score & $\begin{array}{l}\text { Standard } \\
\text { Deviation }\end{array}$ \\
\hline Experimental & 59.67 & 8.899 \\
Control & 58.17 & 9.603 \\
\hline
\end{tabular}

The table shows that the mean scores of experimental group was different with control group before treatment. The mean score in pretest of control group was 58.17 which was categorized as average classification and experimental group was 59.67 which was also categorized as poor classification. It indicated that the mean score of the students' listening comprehension in pretest of experimental group was not quietly different than that of the pretest in control group.

The Mean Score and Standard Deviation of Students' Posttest

\begin{tabular}{|l|l|l|}
\hline Group & $\begin{array}{l}\text { Mean } \\
\text { Score }\end{array}$ & $\begin{array}{c}\text { Standard } \\
\text { Deviation }\end{array}$ \\
\hline Experimental & 76.50 & 5.894 \\
Control & 63.50 & 7.328 \\
\hline
\end{tabular}

The table 4.8 shows that the mean scores of experimental group was different with control group after the treatment. The mean score in posttest of control group was 63.50 which categorized fair at table 4.3. and 76.50 for experimental group which was categorized as good classifications at table 4.1. It indicated that the mean score of the students' listening comprehension in posttest of experimental group was strictly higher than that of the posttest of control group in scale of 13 points.

The T-test Value of the Students' Pretest on Experimental/Control Group

\begin{tabular}{|l|l|l|l|l|}
\hline Variables & $\begin{array}{l}\text { t-test } \\
\text { value }\end{array}$ & $\begin{array}{l}\text { Mean } \\
\text { difference }\end{array}$ & df & $\begin{array}{l}\text { Sig. } \\
(2 \\
\text { tailed })\end{array}$ \\
\hline Pretest & .628 & 1.500 & 58 & .533 \\
\hline
\end{tabular}

Based on the result of data analysis as summarized in Table 4.7 above on pretest of experimental/control group, the researcher found that the t-value (.628), the degree of freedom 58 and p-value (0.533) was greater than .05 of the level significance. It implied that there was no a significant difference between the learning outcomes of the students' listening comprehension of the two groups in the beginning of the research.

The T-test Value of the Students' Posttest on Experimental/Control Group

\begin{tabular}{|l|l|l|l|l|}
\hline Variables & $\begin{array}{c}\text { t-test } \\
\text { value }\end{array}$ & $\begin{array}{l}\text { Mean } \\
\text { difference }\end{array}$ & df & $\begin{array}{l}\text { Sig. (2 } \\
\text { tailed) }\end{array}$ \\
\hline Posttest & 7.571 & 13.000 & 58 & .000 \\
\hline
\end{tabular}

score of the posttest as the final result into the t-test formula for independent sample, the writer found that the t-test (7.571), pvalue (.000) was not greater than .05 of 
the level of significance. It implied that there was a significant difference between the learning outcomes of the students' listening comprehension of the two groups after treatment of the research.

The t-test of the students' pretest and posttest in control and experimental group

\begin{tabular}{|l|l|l|l|}
\hline Variable & $\alpha$ & $\begin{array}{l}\text { P- } \\
\text { Value }\end{array}$ & Remarks \\
\hline $\begin{array}{l}\text { Pretest and } \\
\text { posttest of } \\
\text { control group }\end{array}$ & .05 & .533 & $\begin{array}{l}\text { Not } \\
\text { Significantly } \\
\text { different }\end{array}$ \\
\hline $\begin{array}{l}\text { Pretest and } \\
\text { posttest of } \\
\text { experimental } \\
\text { group }\end{array}$ & .05 & .000 & $\begin{array}{l}\text { Significantly } \\
\text { different }\end{array}$ \\
\hline
\end{tabular}

above, it is concluded that the probability value is smaller than the level of significance $.05(.000<.05)$. It means that $\mathrm{H}_{1}$ was accepted and $\mathrm{H}_{0}$ was rejected. It is concluded that there is a significant difference before treatment in pretest and after treatment in posttest both for control and experimental group. In other words, there was an improvement on the students' listening comprehension between pretest and posttest in control and experimental group after the treatment. Then, it is concluded that both using folktales non using folktales are able to give significantly greater contribution to the students' integrated skills performance.

4. Students Motivation of the Tenth Year Students' of SMA I Parepare in Learning listening comprehension by using folktales.

The Students' Motivation in Learning listening comprehension by using Folktales.

\begin{tabular}{|l|l|l|c|c|}
\hline No & $\begin{array}{l}\text { Classificati } \\
\text { on }\end{array}$ & Range & F & \% \\
\hline 1. & $\begin{array}{l}\text { Very High } \\
\text { motivated }\end{array}$ & $88-100$ & 6 & 20 \\
\hline 2. & $\begin{array}{l}\text { Strong } \\
\text { Motivated }\end{array}$ & $71-87$ & 24 & 80 \\
\hline 3. & Moderate & $54-70$ & 0 & 0 \\
\hline 4. & $\begin{array}{l}\text { Weak } \\
\text { motivated }\end{array}$ & $37-53$ & 0 & 0 \\
\hline 5. & $\begin{array}{l}\text { Very Weak } \\
\text { motivated }\end{array}$ & $20-36$ & 0 & 0 \\
\hline Total & 30 & 100 \\
\hline
\end{tabular}

This was evidenced by the fact that the frequency of the students' students' learning outcomes on listening improved. The questionnaire as the basis for this statement obviously indicates that most of the students $6(80 \%)$ out of 30 students were categorized as very high motivated, $24(80 \%)$ out of them were categorized as strong motivated, and none of them belong to moderate, weak motivated, and very weak motivated. Thus, the mean score achieved 83.83.

Based on the scoring classification of students' questionnaire stated in previous chapter, the mean score of students' motivation is 83.83 classified as strong motivated. It reveals that the eleventh year's students' of SMA Negeri I Parepare had strong motivation in learning listening folktales as the media.

\section{CONCLUSION AND SUGGESTION}

The use of folktales in teaching listening comprehension significantly improves the listening comprehension of the eleventh semester students of SMA NEGERI 1 Parepare. It was proved by the analysis of test that shows the mean score of posttest is greater than pretest $\left(\mathrm{X}_{\text {posttest }}=\right.$ $63.50>X_{\text {pretest }}=58.17$ ). It can be also seen through the result of table paired sample $(.000<.05)$. This output indicates that there is a significant difference between pretest and posttest of experimental group. It means that the use of folktales in teching listening comprehension gives significantly greater contribution. Besides that the researcher concluded that The use of folktales in teaching listening comprehension in the classroom motivated the eleventh semester students of SMA Negeri 1 Parepare. The means score achieved 83.83 was classified into Strong motivated classification. They were motivated to learn listening by using folktales. The data showed that the degree of the students' motivation was very high. It was proved by the students' score with using Likert scale.

Based on the conclusion above, the researcher put some suggestions and recommendation. It is advisable to the 
English teacher to use folktales I teaching listening as one of alternative strategy or media in teaching listening in order to improve students' listening comprehension, The teacher, who teaches English at the eleventh year students, applies " folktales in teaching listening" should allocate more time in teaching listening because the finding of this research also showed that the students' interest is higher than conventional way, It is also suggested to future researchers to conduct a similar topic and level to focus their attention in measuring the quality of the students' listening and finding some problems faced by SMA students in learning listening or the teacher need to consider the students' level (who), materials (what), venue (where), and time (when) the teaching and learning process taken place in order the implementation of folktales effectively.

\section{REFERENCES}

Anderson, Anne \& Lynch, Tony. Listening .Oxford. : Oxford University Press.

Anderson, Lorin W. 1989. Research in Classrooms. Oxford: Pergamon Press.

Anna Maria schwatrz. 1998. Listening in foreign language. Modules for professional preparation of teaching assistant in foreign Languages. (http://www.nclrc.org)

Arsyad, Azhar. 2004. Media Pembelajaran. Jakarta: Raja Grafindo Persada.

Brown, H. Douglas. 1999. Principles of Language Learning and Teaching. America: Prentice-Hill Inc.

Brown, H, Douglas. 2001. Teaching by Principles: An Interactive Approach to Language Pedagogy. San Francisco State University: Longman.

Brown, H, Douglas and Gonzo, Susan T. 1995. Reading In Second Language Aqcuisition. TESL Canada Jurnal vol 13, no 1 Winter 1995.

Buck, Gary 2001. Assessing Listening. New York: Cambridge University press. 2001.
Burden, Paul R. \& Byrd, David M. 1999. Effective Teaching. Second Edition. America: Kansas State University.

Clark, Herbet H and Clark, eve V. 1977. Psychology and Language: An Introduction to Psycholinguistics. New York: Harcourt Brace Jovan Idch Inc

Coulson, D. 1978. The New Oxford Illustrated Dictionary. Tokyo: Toppan Printing Company Cullen, Brian (199). Song Dictation. The internet TESL Jurnal.

Cunningsworth, Alan. 1987. Evaluating and Selecting EFL Teaching Materials. London: Heinemann Educational Books.

David Emery. Kinds of folktales. (http://urbanlegends.about.com)

Depdiknas. 2005. Petunjuk Pelaksanaan Proses Belajar Mengajar dan Petunjuk Pelaksanaan Sistem Penilaian. Jakarta: BSNP

Ellies, R. 1994. The study of second language acquisition. Oxford: Oxford University Press.

Erick. Taylor. 2000. Using Folktales. Cambridge Handbooks for Language Teachers.

Etman, Djodi. 2009. Teaching Listening Comprehension. Ministry of national Education.

Gay, L.R., E. Mills, Peter Airasian. 2006. Educational Research:

Competencies for Analysis and Applications. New Jersey: Prentice Hall.

Gebhard, Jerry G. 2000. Teaching English as a foreign or second language. USA. The University of Machigan Press

Hansan, A. (2000). Learners' perceptions of listening comprehension problems.

Harmer, Jeremy. 1991. The Practice of English Language Teaching. London: Longman Group Ltd

Heaton, J.B. 1988. Writing English Language Tests. New York: Longman Group UK Company 
Hornby, A.S.1995. Oxford Advanced Learners' Dictionary. $5^{\text {th }}$ ed. NY: Oxford University Press.

Howatt. A. and Dakin (1974). Language laboratory materials. Oxford: university press.

Irmawati. 2008. Improving students' listening comprehension through kangaroo radio English in the classroom.

Kirkpatrick, Betty. 1993. Giant Paperback Dictionary. London: The Bath Press.

Merriam-Webster's Medical Dictionary. 2002. Merriam-Webster Online Dictionary. http: //www.mw.com/dictonary/. Merriam-Webster Inc.

Mitchell. R \& Myles. F. 1996. Second Language Learning Theories. London: Hodder Headline Group.

Muhtar, rosmawati (2010). Teaching folktales in teaching reading to the second years students of SMP Negeri 6 Makassar.

Naiman, N., Froelic. 1978. The Good Language Learner. Toronto: Ontario Institute for Studies in Education

Noni Nurdin. 2004. A Hybrid of face-toface Teaching and Computer Assisted Language Learning to Improve Students' English Achievement Based an Individual Learning Preferences. Unpublished Dissertation. Makassar: PPs UNM.

Puspani, Ida Ayu Made 2011. Teaching Listening and Speaking to Young
Learners

Folktale.Academic Journal

Through

Savile-Troike, Muriel. 1976. Foundation for Teaching English as a Second Language. New Jersey: Prentice Hall Inc.

S Hornby. 1995. Oxford Advanced Learne's Dictionary. Sixth Edition. New York: Oxford University Press

Syaodih. N. S. 2008. Metodologi Penelitian Pendidikan. Bandung: Remaja Rosdakarya.

Rost, Michael. 1990. Listening in Language Learning. London: Longman.

Taylor, Eric K. 2000. Using Folktales. USA. Cambridge University Press.

Taylor, Janusik Laura Ann (2004) . Listening what the research says to the teacher. Washington, DC: National education in association.

Tina L Hanlon 1999. General guidelines for teaching with folktales. Ferrum College. (http://www2.ferrum.edu)

Wang Shouyuan in Huaru Chen (2003). Brief analysis of Strategies to improve listening comprehension competence among non-english undergraduate students. Asian social sciences vol. 7. No 12.

Widdowson, H.G. 1985. Teaching Language as a Communication. Oxford: Oxford University Press.

White, Goodith. 1998. Listening. Oxford: Oxford University Press. 